\title{
Effect of breeder age and storage conditions of Japanese quail eggs on hatchability, quail neonate quality, and Bursa of Fabricius characteristics
}

\author{
Itallo Conrado Sousa de Araújo ${ }^{1 *}$, Mariana Alves Mesquita ${ }^{1}$, Marcos Barcellos Café1, José \\ Henrique Stringhini ${ }^{1}$, Paulo Henrique Sousa da Paz ${ }^{1}$, Raiana Almeida Noleto ${ }^{1}$, Nadja Susana \\ Mogyca Leandro ${ }^{1}$
}

${ }^{1}$ Universidade Federal de Goiás, Escola de Veterinária e Zootecnia, Goiânia, GO, Brazil.

\begin{abstract}
Two experiments were conducted to evaluate combinations of different storage periods and temperature of hatching eggs of breeder quails in two stages of the production cycle (24 and 43 weeks) on hatchability, quail neonate quality, and Bursa of Fabricius characteristics. In each experiment, a total of 1.050 Japanese quail eggs were incubated in a randomized block design in a factorial arrangement of $2 \times 5 \times 2$, with two breeder ages ( 24 and 43 weeks), five storage periods (one, three, six, nine, and twelve days), and two storage temperatures $\left(28\right.$ and $\left.14{ }^{\circ} \mathrm{C}\right)$, totaling 20 treatments with 52 eggs each. Quantitative data were subjected to ANOVA and means were compared by Tukey's test. Qualitative data were subjected to Friedman's test. Polynomial regression analysis was performed in relation to the storage period of the eggs. Hatchability of 43-week-old breeders worsened as the storage period increased at $28{ }^{\circ} \mathrm{C}$, while at $14{ }^{\circ} \mathrm{C}$, hatchability was not affected. Yolk-free body weight was influenced only by storage period; therefore, the group stored for 12 days had the lowest yolk-free body weight. Twelve days of storage reduced the absorption of yolk residue and physical quality score and also affected neonate quail immunity. Fertile eggs from Japanese quails that are destined for incubation should be stored at $14{ }^{\circ} \mathrm{C}$ to maintain physical and immunological quality of the progeny. Moreover, eggs from older breeders originate lower-quality quails when eggs are not stored in a refrigerated environment.
\end{abstract}

Key Words: Coturnix coturnix japonica, fertile egg, flock age, immunity, quail production

\section{Introduction}

Brazilian quail farming has presented high growth over recent years. The main factors that have driven this development are the low investment needed for the infrastructure, little space necessary for the activity, sexual precocity and good laying rate of the birds, and the low feed intake (Teixeira et al., 2013). Another factor is that major commercial egg-producing companies are also entering the market as quail-egg producers.

However, there is still a limitation regarding the availability of day-old quails for substitution in the farms, especially in relation to genetic, physical, and immunological quality of these birds. To ensure the quality of neonate quails on the market, the characteristics of this

\footnotetext{
Received: December 12, 2016

Accepted: March 22, 2017

*Corresponding author: italloconradovet@hotmail.com

http://dx.doi.org/10.1590/S1806-92902017000900004
}

How to cite: Araújo, I. C. S.; Mesquita, M. A.; Café, M. B.; Stringhini, J. H.; Paz, P. H. S.; Noleto, R. A. and Leandro, N. S. M. 2017. Effect of breeder age and storage conditions of Japanese quail eggs on hatchability, quail neonate quality, and Bursa of Fabricius characteristics. Revista Brasileira de Zootecnia 46(9):731-739

Copyright (c) 2017 Sociedade Brasileira de Zootecnia. This is an Open Access article distributed under the terms of the Creative Commons Attribution License (http://creativecommons.org/licenses/by/4.0/), which permits unrestricted use, distribution, and reproduction in any medium, provided the original work is properly cited. species need to be studied, along with factors that affect embryonic development and consequent yield in the incubator. According to Araújo et al. (2015), to this day, the methods used for incubation of fertile eggs by breeding quails are based on parameters determined through studies on broiler breeders.

Just as with broiler chicks, the quality of neonate quails will influence their growth performance in the field. Moreover, there are several factors that can affect the quality of quails. According to Nazareno et al. (2014), in a study on incubation of Japanese quail breeders, the main factors regarding variation of hatching results were in relation to the storage condition of the eggs before incubation, the health of the batch of reproducers, and the age of the breeders. Likewise, Mahmud et al. (2011) reported that the physicochemical quality of eggs stored for long periods of time diminished, which led to losses in relation to embryo development and survival, thus harming the incubation results.

In a study on hatching, Pedroso et al. (2006) concluded that quail fertile eggs could be stored for a maximum of $72 \mathrm{~h}$ when the room temperature was $26.5^{\circ} \mathrm{C}$. Araújo et al. (2015) concluded that quail fertile eggs could be stored without harming the hatch of eggs for six days at $28^{\circ} \mathrm{C}$ and nine days on $14{ }^{\circ} \mathrm{C}$. However, in most quail incubators, storage is not 
done under refrigeration, the eggs are usually kept at room temperature.

Regarding breeder age, Tanure et al. (2009) studied laying breeders and observed that the age of the breeder influenced incubation and the quality and performance of the progeny during the growth period. When breeders become old, the egg shell begins to have greater capacity for gas and water vapor exchanges between the embryo and the environment. This occurs due to the number and dimension of pores and thickness and resistance of the shell, along with the environmental conditions in the egg room (Barbosa et al. 2008; Zakaria et al., 2009). Thus, studies are needed to generate information for incubation decisions.

In this light, the objective of the present study was to determine the effect of storage period and temperature on hatching eggs from reproductive quails from two different age groups, during the production cycle, taking into consideration the egg hatching and the physical and immunological quality of the neonate quails.

\section{Material and Methods}

The local Ethical Committee on Animal Use approved all procedures used in this study. Two experiments were conducted at two different stages of production cycle (breeders with 24 and 43 weeks). In each experiment, a total of 1,050 fertile Japanese quail eggs were incubated. In both assays, 100 fresh eggs were collected to evaluate the fertility of the batch, which was found to be $82 \%$ when breeders were 24 weeks old and $75 \%$ when they were 43 weeks old. The egg storage room was monitored twice a day and the mean room temperature was $28^{\circ} \mathrm{C}$.

The eggs were incubated in a randomized block design in a factorial arrangement $(2 \times 5 \times 2)$, with two breeder ages ( 24 and 43 weeks), five storage periods (one, three, six, nine, and 12 days), and two storage temperatures $\left(28\right.$ and $14{ }^{\circ} \mathrm{C}$ ), totaling 20 treatments with 52 eggs each. Each machine was considered a block and each egg was a experimental unit.

The eggs were selected and standardized regarding their characteristics of capacity for incubation and weight. After storage period, the eggs were uniformly distributed into four incubators (automatic Premium Ecológica ${ }^{\circledR}$ ), with capacity for 300 eggs each. The incubators were adjusted to maintain the temperature at a constant $37.9{ }^{\circ} \mathrm{C}$ and the relative humidity at $60 \%$. The eggs were placed horizontally and turned every two hours. On the sixteenth day of incubation, the incubators were programed to stop turning the eggs over. The hatching of the quails was monitored every two hours starting from the 426th hour. The experiment was finished upon completion of $440 \mathrm{~h}$ of incubation. Quails that had wet plumage $(1.2 \%)$ at the withdrawal were not considered for the evaluation of hatching and physical quality.

Egg hatching was compared to the percentage of fertile eggs. To evaluate the quality of neonate quails, birds that presented dry plumage were removed from the incubators, weighed, and then subjected to a physical quality evaluation in accordance with a score system from 0 to 100, as proposed by Tona et al. (2003), being evaluated in chick quality: activity, down and appearance, retracted yolk, eyes, legs, navel area, remaining membrane, and remaining yolk. To evaluate the development of the digestive system, bursa of Fabricius, and yolk residue, 15 neonate quails from each treatment were slaughtered by means of cervical dislocation and their yolk residue and small intestine plus pancreas were weighed.

The following variables were studied: hatching in relation to fertile eggs (\%), physical quality score; weight of the quail at hatching $(\mathrm{g})$; percentage of residual yolk weight (residual yolk weight $\times 100$ /quail weight at hatching); yolk-free body weight (g); weight of the small intestine plus pancreas:quail weight ratio (\%); and length of the small intestine $(\mathrm{cm})$.

In a histomorphometric study, the follicle area of the bursa of Fabricius of the neonate quails was evaluated as described by Leandro et al. (2011), using an image analysis system (UTHSCSA ImageTool software, version 3.0) and an area of five follicles per bursa of Fabricius was measured (in $\mathrm{mm}^{2}$ ). A total of 300 bursas were analyzed, 15 bursas per treatment such that each bursa was one experimental unit.

To evaluate the integrity of the bursa of Fabricius, the lymphocyte depletion was quantified. The bursas were fixed in neutral-buffered formalin. Afterwards, tissues were processed according to the conventional methods on hematoxylin and eosin staining (Luna, 1968) and examined using a light microscope. We analyzed 15 bursas per treatment, using an adaptation of the histopathological score proposed by Pereira (2004): score 0 - no lesions; score 1 - edema, slight hyperplasia, follicular lymphoid rarefaction, and acidophilus fluid; score 2 - inflammatory infiltrate, slight atrophy of the follicles, lymphoid rarefaction, and follicular necrosis; score 3 - severe atrophy of the follicles, follicular and epithelial cysts, and fibrosis; and score 4 - complete atrophy of the follicle, follicular cysts, and disseminated points of necrosis. The scores were divided into two groups: $\geq 69 \%$ depletion (scores 3 and 4 ) and $<69 \%$ depletion (scores 0,1 , and 2 ).

All data analysis was evaluated for normality by the Shapiro-Wilk test. After that, the quantitative results of normal distribution of data were subjected to analysis of variance and the means were compared by Tukey's test $(\mathrm{P}<0.05)$. The 
qualitative results were subjected to Friedman's test $(\mathrm{P}<0.05)$. Polynomial regression analysis was performed in relation to the storage period of the eggs. The analyses were carried out using the R software (R Development Core Team, 2011).

\section{Results}

The results regarding the hatching:fertile egg ratio (Table 1) showed that there was no interaction among period, storage temperature, and breeder age $(\mathrm{P}>0.05)$. Breeder age had an effect on this relation $(\mathrm{P}<0.05)$, such that the hatching:fertile egg ratio ranged from $64.09 \%$ for 43 -week-old breeders to $67.01 \%$ for 24 -week-old breeders. No interaction was observed between breeder age and storage temperature $(\mathrm{P}>0.05)$, the same way that no interaction was observed between breeder age and storage time $(\mathrm{P}>0.05)$. However, storage presented interaction $(P<0.05)$ between time and temperature.

Storage time did not affect egg hatching of 24-weekold breeders (Figure 1-A) $(\mathrm{P}>0.05)$ at either storage

Table 1 - ANOVA results for the data on the hatching:fertile eggs ratio for eggs subjected to different storage periods and temperatures, originating from quail breeders of different ages

\begin{tabular}{lc}
\hline \multirow{2}{*}{ Group } & P-value \\
\cline { 2 - 2 } & Hatching:fertile eggs (\%) \\
\hline Age & $0.0458^{*}$ \\
Storage & $<0.0001^{*}$ \\
Age $\times$ storage & 0.4731 \\
Temperature & $0.0036^{*}$ \\
Age $\times$ temperature & 0.9776 \\
Storage $\times$ temperature & $0.0201^{*}$ \\
Age $\times$ storage $\times$ temperature & 0.5514 \\
CV $(\%)$ & 18.00 \\
Regression & $\mathrm{L}$ \\
\hline
\end{tabular}

$\mathrm{CV}$ - coefficient of variation; L - linear.

* Tukey test $(\mathrm{P}<0.05)$. temperatures studied. Egg hatching of older breeders (43 weeks old) decreased linearly with increasing storage period when the eggs were stored at $28^{\circ} \mathrm{C}$. However, when the eggs were stored at $14{ }^{\circ} \mathrm{C}$, there were no hatching losses (Figure 1-B).

Breeder age influenced $(\mathrm{P}<0.05)$ the physical quality score of the neonate quails (Table 2). Quails born from eggs produced by older breeders presented higher physical quality score (93.85) than those of the 24-week-old breeders (86.43). The worst score observed $(\mathrm{P}<0.05)$ was for the neonate quails from eggs stored for 12 days (86.52). The storage temperature of $28{ }^{\circ} \mathrm{C}$ led to worse quality among the quails (89.57), while the temperature of $14{ }^{\circ} \mathrm{C}$ led to better quality (91.36) $(\mathrm{P}<0.05)$.

Breeder age did not affect the weight of the quail at hatching, percentage of residual yolk weight, or yolk-free body weight (Table 2). The storage period influenced all the physical quality parameters of the neonate quails studied. The eggs from 24-week-old breeders presented negative linear effect $(\mathrm{P}<0.05)$ in relation to the weight of the quail when the eggs were stored for up to 12 days, regardless of the storage temperature (Figure 2-A). However, the yolkfree body weight decreased linearly with increasing storage period only when the eggs were stored at room temperature. When the eggs were stored at a temperature of $14{ }^{\circ} \mathrm{C}$, the yolk-free body weight was not influenced by the storage period.

Regarding the 43-week-old breeders, the storage period only affected the weight of the quail at hatching (Figure 2-D) when the eggs were not stored under refrigeration, with lower weight as storage time increased.

The storage period did not influence the weight of the quail at hatching under refrigerated conditions $(\mathrm{P}>0.05)$. However, considering the yolk-free body weight of the quails, there was no regression effect regarding storage period $(\mathrm{P}>0.05)$.

Table 2 - Physical quality of neonate quails from breeders of different ages, subjected to different storage periods and temperatures

\begin{tabular}{lcccc}
\hline \multirow{2}{*}{ Group } & \multicolumn{4}{c}{ P-value } \\
\cline { 2 - 5 } & Quality score & Weight of the quail & Weight of the yolk residue/weight of the quail & Net weight of the quail \\
\hline Age & $<0.0001^{*}$ & 0.7611 & 0.3416 & 0.5739 \\
Storage & $0.0470^{*}$ & $0.0490^{*}$ & $<0.0001^{*}$ & $0.0003^{*}$ \\
Age $\times$ storage & 0.5623 & 0.6153 & 0.2179 & 0.5919 \\
Temperature & $0.0050^{*}$ & 0.6419 & 0.5243 & 0.8857 \\
Age $\times$ temperature & 0.2641 & 0.4950 & 0.4887 & 0.3595 \\
Storage $\times$ temperature & 0.0890 & 0.2387 & 0.1206 & 0.1436 \\
Age $\times$ storage $\times$ temperature & 0.1540 & 0.9011 & 56.27 & 0.9293 \\
CV $(\%)$ & 12.11 & 10.87 & $\mathrm{~L}$ & 11.05 \\
Regression & $\mathrm{NS}$ & $\mathrm{L}$ & $\mathrm{L}$
\end{tabular}

$\mathrm{CV}$ - coefficient of variation; NS - not significant; L - Linear.

* Tukey test $(\mathrm{P}<0.05)$. 
A low ratio indicates that the neonate bird adequately used the nutritional input supplied by the egg (Figure 3). Greater weight of the percentage of residual yolk weight $(\mathrm{P}<0.05)$ occurred with increasing egg storage period. However, for eggs from younger breeders, storage at a refrigerated temperature enabled a better relationship between the weight of the quail and the weight of the yolk residue, thus indicating greater absorption of the yolk residue and, therefore, better quality among the neonate quails.

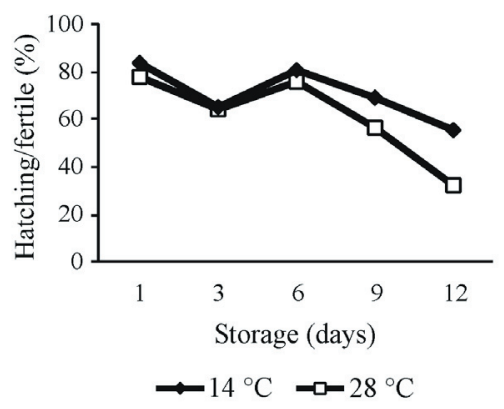

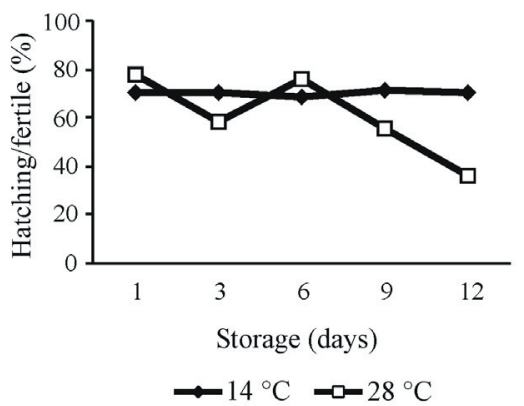

24-week-old breeder/temperature at $28^{\circ} \mathrm{C}$. P-value $=0.0890$

24-week-old breeder/temperature at $14{ }^{\circ} \mathrm{C}$. P-value $=0.4960$.

43-week-old breeder/temperature at $28^{\circ} \mathrm{C} . \mathrm{Y}=82.09-3.09^{*}$ period. $\mathrm{r}^{2}=0.76 . \mathrm{P}$-value $=0.0038$

43-week-old breeder/temperature at $14{ }^{\circ} \mathrm{C}$. P-value $=0.9354$

Figure 1 - Percentage of hatching in relation to fertile eggs from breeders of 24 (A) or 43 (B) weeks of age, stored at temperatures of 14 or $\pm 28{ }^{\circ} \mathrm{C}$ for different periods.

A
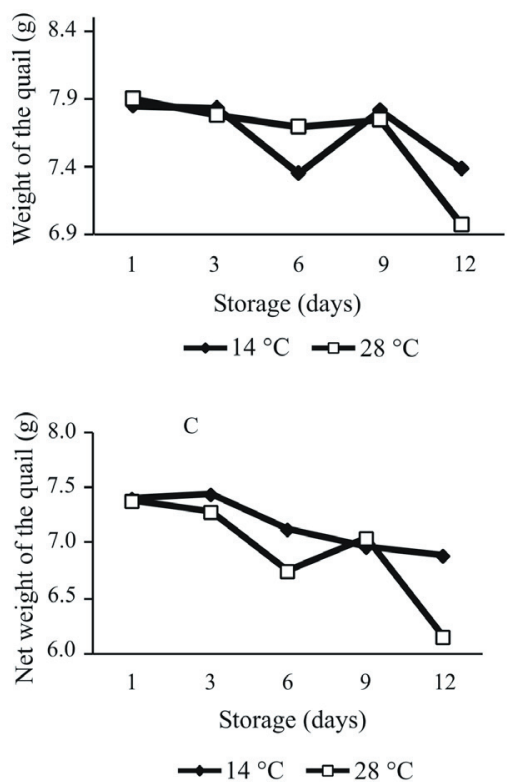

B

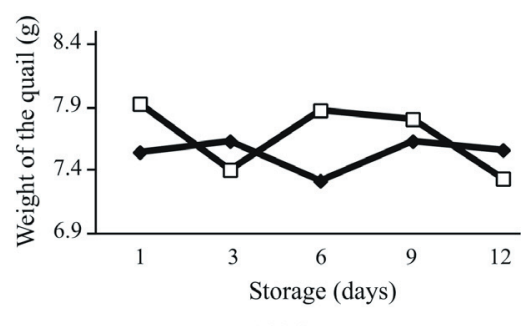

$\rightarrow 14^{\circ} \mathrm{C} \rightarrow-28^{\circ} \mathrm{C}$

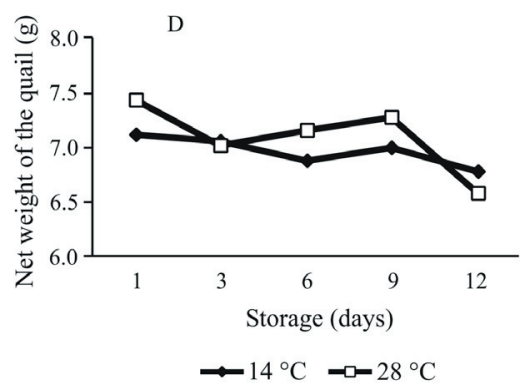

Weight of the quail:

24-week-old breeder/temperature at $28^{\circ} \mathrm{C} . \mathrm{Y}=8.03-0.065^{*}$ period. $\mathrm{r}^{2}=0.20 . \mathrm{P}$-value $=0.0096$.

24-week-old breeder/temperature at $14{ }^{\circ} \mathrm{C} . \mathrm{Y}=7.46-0.053 *$ period. $r^{2}=0.14$. P-value $=0.0427$

43-week-old breeder/temperature at $28^{\circ} \mathrm{C} . \mathrm{Y}=7.39-0.052 *$ period. $\mathrm{r}^{2}=0.16 . \mathrm{P}$-value $=0.0390$.

43 -week-old breeder/temperature at $14{ }^{\circ} \mathrm{C} . \mathrm{P}$-value $=0.1287$.

Net weight of the quail:

24-week-old breeder/temperature at $28^{\circ} \mathrm{C} . \mathrm{Y}=7.63-0.094^{*}$ period. $\mathrm{r}^{2}=0.32 . \mathrm{P}$-value $=0.0020$.

24-week-old breeder/temperature at $14{ }^{\circ} \mathrm{C}$. P-value $=0.3922$.

43-week-old breeder/temperature at $28^{\circ} \mathrm{C}$. P-value $=0.4167$.

43-week-old breeder/temperature at $14^{\circ} \mathrm{C}$. P-value $=0.4346$.

Figure 2 - Weight of the quail (g) and net weight of the neonate quail (g) that originated from eggs of 24 or 43 -week-old breeders, stored at temperatures of 14 or $\pm 28^{\circ} \mathrm{C}$ for periods of one, three, six, nine, and twelve days.

A and C: 24-week-old breeders; B and D: 43-week-old breeders. 
The intestine relative weight was not influenced $(\mathrm{P}>0.05)$ by any of the factors studied (Table 3$)$. The follicle area of the bursa of Fabricius presented an interaction with the factors studied $(\mathrm{P}<0.05)$.

Storing the eggs for 12 days at room temperature showed to be harmful to the intestinal development of the birds (Table 4).

Table 3 - Physical and immunological quality of quails from eggs of breeders of different ages stored for different periods at different temperatures

\begin{tabular}{lccccc}
\hline \multirow{2}{*}{ Group } & \multicolumn{4}{c}{ P-value } \\
\cline { 2 - 3 } & \multicolumn{2}{c}{ Physical quality } & & Immunological quality \\
\cline { 2 - 3 } \cline { 5 - 6 } & IW:QW & LI & & FA $\left(\mathrm{mm}^{2}\right)$ & LS (\%) \\
\hline Age & 0.0967 & 0.4809 & & $0.0028^{*}$ & $<0.0001^{*}$ \\
Storage & 0.0992 & $0.0003^{*}$ & $<0.0001^{*}$ & $<0.0001^{*}$ \\
Age $\times$ storage & 0.4293 & 0.7840 & $<0.0001^{*}$ & 0.9844 \\
Temperature & 0.3885 & 0.0630 & $<0.0001^{*}$ & 0.4854 \\
Age $\times$ temperature & 0.6011 & 0.1099 & 0.0660 & 0.2310 \\
Storage $\times$ temperature & 0.3411 & $0.0470^{*}$ & $<0.0001^{*}$ & $0.0205^{*}$ \\
Age $\times$ storage $\times$ temperature & 0.4144 & 0.2799 & $<0.0001^{*}$ & 0.2775 \\
CV $(\%)$ & 22.99 & 13.24 & 18.71 & 4.51 \\
Regression & $\mathrm{NS}$ & $\mathrm{L}$ & $\mathrm{NS}$ & $\mathrm{Q}$ \\
\hline
\end{tabular}

IW:QW - intestine weight:quail weight ratio; LI - length of the small intestine; FA - areas of bursal follicle; LS - lymphocytic lesion score of the bursa of Fabricius; $\mathrm{CV}$ - coefficient of variation; NS - not significant; L - linear; Q - quadratic.

* Friedman test $(\mathrm{P}<0.05)$.
The weight of small intestine of the quails was affected $(\mathrm{P}<0.05)$ by the storage of the eggs (Table 3$)$. There was no effect of any of the treatments on the relation between small intestine weight and neonatal quail weight. However, when the eggs were stored for the same period (12 days) at $14{ }^{\circ} \mathrm{C}$, there were no losses to the length of the small intestine. There was interaction between the storage and the storage temperature of the eggs (Table 4).

The three factors studied interacted among each other for follicle area of the bursa of Fabricius $(\mathrm{P}<0.05)$. For younger breeders, storage of eggs for more than six days was harmful for development of the bursa of the quails, regardless of the temperature at which the fertile eggs were stored (Table 6). However, when the eggs from the 43 -weekold breeders were stored at $14{ }^{\circ} \mathrm{C}$, there was a worsening of the immune system after nine days of storage.

Breeder age affected the score for lymphocytic lesions of the follicles of the bursa of Fabricius among the quails (Table 3 ). Breeders of 43 weeks of age presented a lower percentage of follicles without lesions. The lymphocytic depletion of the bursa of Fabricius among the quails from 24-week-old breeders that were stored at room temperature increased quadratically. On the other hand, the quails from 43-week-old breeders whose eggs were stored at room

Table 4 - Interaction between storage period and temperature in relation to the length of the intestine of neonate quails

\begin{tabular}{|c|c|c|c|c|c|}
\hline \multirow{2}{*}{$\mathrm{T}\left({ }^{\circ} \mathrm{C}\right)$} & \multicolumn{5}{|c|}{ Storage period (days) } \\
\hline & 1 & 3 & 6 & 9 & 12 \\
\hline & \multicolumn{5}{|c|}{ Length of the intestine $(\mathrm{cm})$} \\
\hline 28 & $16.28 \pm 0.71 \mathrm{Aa}$ & $15.26 \pm 0.66 \mathrm{Aa}$ & $15.38 \pm 0.77 \mathrm{Aa}$ & $14.70 \pm 0.34 \mathrm{Aa}$ & $13.13 \pm 0.38 \mathrm{Bb}$ \\
\hline 14 & $16.02 \pm 0.41 \mathrm{Aa}$ & $16.04 \pm 0.38 \mathrm{Aa}$ & $15.24 \pm 0.47 \mathrm{Aa}$ & $14.83 \pm 0.30 \mathrm{Aa}$ & $15.31 \pm 0.41 \mathrm{Aa}$ \\
\hline
\end{tabular}

$\mathrm{T}\left({ }^{\circ} \mathrm{C}\right)$ - storage temperature.

Values followed by different uppercase letters in the column and lowercase letters in the row are different according to Tukey's test (P<0.05).

A

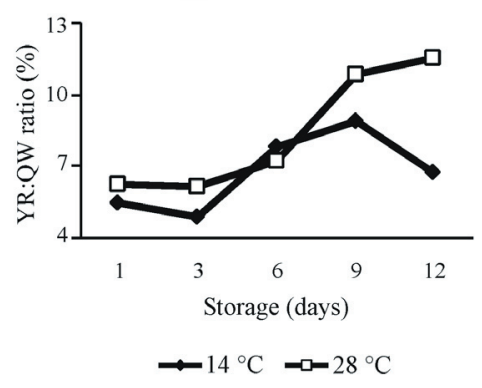

B

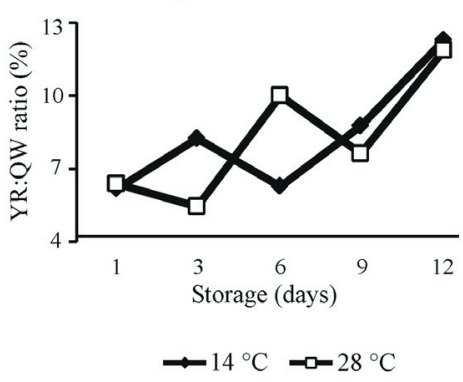

24-week-old breeder/temperature at $28^{\circ} \mathrm{C} . \mathrm{Y}=4.777+0.481 *$ period. $\mathrm{r}^{2}=0.23$. P-value $=0.0009$.

24-week-old breeder/temperature at $14^{\circ} \mathrm{C} . \mathrm{Y}=5.109+0.265^{*}$ period. $\mathrm{r}^{2}=0.33$. P-value $=0.0299$.

43 -week-old breeder/temperature at $28^{\circ} \mathrm{C} . \mathrm{Y}=5.571+0.486^{*}$ period. $\mathrm{r}^{2}=0.17$. P-value $=0.0146$.

43-week-old breeder/temperature at $14{ }^{\circ} \mathrm{C} . \mathrm{Y}=5.437+0.483 *$ period. $\mathrm{r}^{2}=0.21$. P-value $=0.0036$.

Figure 3 - Relationship between the weight of the yolk residue (YR) and the weight of the neonate quails (QW) (\%) originated from 24 or 43-week-old breeders, stored at temperatures of 14 or $\pm 28{ }^{\circ} \mathrm{C}$ for periods of one, three, six, nine, and twelve days.

A: 24-week-old breeders; B: 43-week-old breeders. 
temperature did not present effect $(\mathrm{P}>0.05)$ for lymphocytic depletion. Quadratic behavior $(\mathrm{P}<0.05)$ was only observed when the eggs were stored at room temperature (Figure 4).

In the development interaction between the age of the breeder quail and storage period and temperature of the eggs in relation to the bursal follicle area of the progeny (Table 5), egg storage for up to six days, regardless of the temperature and breeder age, did not lead to losses in immunological quality of the birds. However, when storage lasted for nine days, eggs needed to be refrigerated to minimize the effect of storage on the bursal follicle area of the neonate quails.

\section{Discussion}

Based on our review of the literature, it was not possible to find many studies evaluating the interaction between the age of the breeders and the egg storage conditions for Japanese quails; however, there are several studies with eggs from broiler breeders.
A

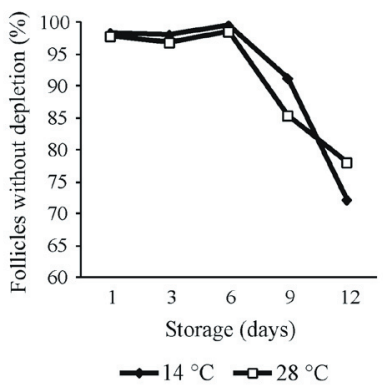

B

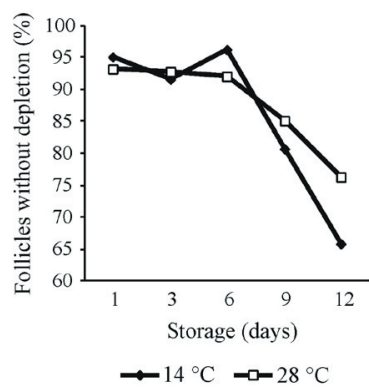

Regressions

24-wk-old breeder/temperature at $28^{\circ} \mathrm{C} . \mathrm{Y}=105.1227-1.6984^{*}$ period- $0.2205^{*}(\text { period-6) })^{2} . \mathrm{r}^{2}=0.89 . \mathrm{P}$-value $=0.0491$.

24-wk-old breeder/temperature at $14^{\circ} \mathrm{C}$. P-value $=0.4824$

43-wk-old breeder/temperature at $28^{\circ} \mathrm{C}$. P-value $=0.8753$.

43-wk-old breeder/temperature at $14{ }^{\circ} \mathrm{C} . \mathrm{Y}=106.3846-2.3201 *$ period- $0.387 *(\text { period- } 6.2)^{2} \cdot \mathrm{r}^{2}=0.95$. P-value $=0.0025$

Figure 4 - Lymphocytic depletion of the follicles of the bursa of Fabricius in the neonate quails that originated from eggs from 24 or 43 week-old breeders, stored at temperatures of 14 or $\pm 28{ }^{\circ} \mathrm{C}$ for periods of one, three, six, nine, and twelve days.

A: 24-week-old breeders; B: 43-week-old breeders.

Table 5 - Interaction between the age of the breeding quails and storage period and temperature of the eggs in relation to the bursal follicle area of the progeny

\begin{tabular}{|c|c|c|c|c|c|c|}
\hline \multirow{2}{*}{ Age } & \multirow{2}{*}{$\mathrm{T}\left({ }^{\circ} \mathrm{C}\right)$} & \multicolumn{5}{|c|}{ Storage period (days) } \\
\hline & & 1 & 3 & 6 & 9 & 12 \\
\hline & & \multicolumn{5}{|c|}{ Bursal follicle area $\left(\mathrm{mm}^{2}\right)$} \\
\hline \multirow{2}{*}{24 weeks } & 28 & $3.190 \pm 0.58 \mathrm{Ba}$ & $3.421 \pm 0.35 \mathrm{Ba}$ & $3.096 \pm 0.43 \mathrm{Ba}$ & $2.523 \pm 0.17 \mathrm{Bb}$ & $2.170 \pm 0.33 \mathrm{Bb}$ \\
\hline & 14 & $2.840 \pm 0.71 \mathrm{Ba}$ & $3.028 \pm 0.31 \mathrm{Ba}$ & $2.370 \pm 0.61 \mathrm{Ba}$ & $2.058 \pm 0.24 \mathrm{Ba}$ & $3.110 \pm 0.59 \mathrm{Ba}$ \\
\hline \multirow[t]{2}{*}{43 weeks } & 28 & $5.743 \pm 0.52 \mathrm{Aa}$ & $5.834 \pm 0.52 \mathrm{Aa}$ & $4.570 \pm 0.17 \mathrm{Ba}$ & $2.745 \pm 0.34 \mathrm{Bb}$ & $0.876 \pm 0.21 \mathrm{Bc}$ \\
\hline & 14 & $6.601 \pm 0.44 \mathrm{Aa}$ & $5.776 \pm 0.61 \mathrm{Aa}$ & $5.363 \pm 0.23 \mathrm{Aa}$ & $3.175 \pm 0.41 \mathrm{Bb}$ & $1.091 \pm 0.23 \mathrm{Bc}$ \\
\hline
\end{tabular}

$\mathrm{T}\left({ }^{\circ} \mathrm{C}\right)$ - storage temperature.

Values followed by different uppercase letters in the column and lowercase letters in the row are different according to Tukey's test ( $\mathrm{P}<0.05$ ).

Table 6 - Development of the interaction between storage period and temperature of the quail eggs in relation to the percentage of the follicles of the bursa of Fabricius which did not present severe lymphocytic lesions*

\begin{tabular}{lcccc}
\hline $\mathrm{T}\left({ }^{\circ} \mathrm{C}\right)$ & \multicolumn{4}{c}{ Storage period (days) } \\
\cline { 2 - 5 } & & 3 & 6 & 9 \\
28 & $95.64 \pm 1.18 \mathrm{Aa}$ & Follicles without severe lymphocytic lesions $(\%)$ & \\
14 & $96.75 \pm 0.98 \mathrm{Aa}$ & $94.75 \pm 1.58 \mathrm{Aa}$ & $95.36 \pm 1.18 \mathrm{Aa}$ & $83.56 \pm 1.52 \mathrm{Ab}$ \\
\hline
\end{tabular}

$\mathrm{T}\left({ }^{\circ} \mathrm{C}\right)$ - storage temperature.

* Severe or complete atrophy of follicles, follicle and epithelial cysts, and disseminated points of necrosis.

Values followed by uppercase letters in the column and lowercase letters in the row are different according to Friedman's test $(\mathrm{P}<0.05)$. 
Hatching of 43-week Japanese quail breeders remained satisfactory for all storage periods when stored under refrigeration, while hatching of quail chicks kept in room temperature $\left( \pm 28{ }^{\circ} \mathrm{C}\right)$ was impaired from nine days of storage. There was a linear negative effect on the weight of the neonatal quail chicks from the 24-week-old breeders; for 43-week-old breeders, the same effect was observed only in storage at room temperature.

For younger breeders, storage of eggs for more than six days was harmful for the development of the bursa of the quails, regardless of the temperature at which the fertile eggs were stored. However, when the eggs from the 43-week-old breeders were stored at $14{ }^{\circ} \mathrm{C}$, there was a worsening of the immune system after nine days of storage. The lymphocytic depletion of the bursa of Fabricius among the quails from 24-week-old breeders that were stored at room temperature increased quadratically. On the other hand, the quails from 43 -week-old breeders whose eggs were stored at room temperature did not present any effect $(\mathrm{P}>0.05)$ for lymphocytic depletion. Quadratic behavior $(\mathrm{P}<0.05)$ was only observed when the eggs were stored at room temperature (Figure 4).

In the interaction between the age of the breeder quail and storage period and temperature of the eggs in relation to the bursal follicle area of the progeny, egg storage for up to six days, regardless of the temperature and breeder age, did not lead to losses in immunological quality of the birds. However, when storage lasted for nine days, eggs needed to be refrigerated to minimize the effect of storage on the bursal follicle area of the neonate quails.

The results regarding the hatching:fertile egg ratio corroborate those of Santos et al. (2015), who studied quail breeders of different ages and also found that older quails (48 weeks) had worse results for egg hatching than those of younger breeders (20 weeks old) and corroborate those of Araújo et al. (2016), who studied broiler breeders of different ages and also found that older quails (59 weeks) had worse results for egg hatching than those of younger breeders (29 or 35 weeks). According to Almeida et al. (2006), the lower rate of egg hatching among older breeders can be explained by the poorer quality of the shell, which results in a high rate of embryo mortality.

A refrigerated environment reduces losses of egg moisture to the environment (Lemos et al., 2014). This effect was observed more clearly in the eggs from older breeders, for which refrigeration possibly reduced the dehydration of the egg during storage, thus ensuring better hatchability in relation to eggs stored at room temperature.
The results of chick weight with or without yolk sac corroborate the findings of Rocha et al. (2008) and Nangsuay et al. (2013), who did not observe any influence of age of broiler breeders on the weight of the yolk residue of one-day-old chicks. However, results differ from those obtained by Riccardi et al. (2009), who studied the weight of the yolk residue of broiler chicks originated from breeders of different ages and found that chicks from older breeders presented greater yolk weight. According to Molenaar et al. (2008), the lower ratio between the weight of the yolk residue and weight of the quail means better absorption of the maternal nutritional input, which may result in better bird performance. Garip and Deri (2011) studied storage periods for quail eggs and found that short storage at a temperature of $27^{\circ} \mathrm{C}$ was not harmful for the weight of the neonate quails, but when the period was longer, even under lower temperature conditions, there was a weight loss for the neonate quails.

According to Gomes et al. (2007), greater development of the small intestine can be a way for the metabolism of the animal to respond to better nutrient absorption from the ingested food. Thus, the greater the length of the intestine, the more extensive is the area over which the nutrients are exposed to the intestinal cells. Flauzina (2007) observed that the size of the intestines of Japanese quails can affect the passage rate through the digestive tract and the efficiency of the digestive process and absorption of nutrients in their diet.

The bursa of Fabricius is indispensable to the development and functioning of the peripheral lymphoid tissue and to the ability to maintain humoral immunity. Stressful factors can also cause depletion of immature lymphocytes, intensified by apoptosis (Vieira et al. 2007). According to Pereira (2004), a smaller bursal follicle area may indicate immunosuppression. According to Merlot et al. (2008), the immune system of neonate birds is immature and development of the follicles of the bursa is of fundamental importance, because this is an indication of improvement of the defense capacity of these birds against pathogens.

The harm caused to the immune system due to high environmental temperature during incubation was demonstrated by Oznurlu et al. (2010), who reported that the development of the bursa and thymus was reduced by temperatures higher than those recommended for the incubation of chicken eggs. This effect could be observed among one-week-old chicks through clinical signs of immunosuppression (uneven growth, low weight gain, high food conversion, respiratory reactions, and outbreaks 
of various diseases, among others). The results show that storing eggs at high temperatures is harmful to the development of the immune system of the birds.

\section{Conclusions}

Breeder age should be considered as a factor that influences quail progeny responses to physical and immunological quality. Quail eggs intended for incubation should be refrigerated $\left(14{ }^{\circ} \mathrm{C}\right)$ during storage when this period exceeds six days to maintain or improve the physical and immunological quality of the progeny. Differences in the breeder age and storage conditions of fertile quail eggs may affect the development of the bursa of Fabricius at hatching. Eggs from older breeders give rise to poorerquality quails when the eggs are not stored in a refrigerated location before incubation.

\section{Acknowledgments}

We thank the Conselho Nacional de Desenvolvimento Científico e Tecnológico $(\mathrm{CNPq})$ for their support in conducting the research and for the opportunity of the academic master's scholarship granted to the first author.

\section{References}

Almeida, I. C. L.; Mendes, A. A.; Quinteiro, R. R.; Vulcano, L. C.; Takahashi, S. E.; Garcia, R. G.; Komiyama, C. M.; Balog, A.; Pelicia, K.; Wescheler, F. S. and Piccini, A. 2006. Bone mineral density of tibia and femur of broiler breeders: growth, development and production. Brazilian Journal Poultry Science 8:75-82.

Araújo, I. C. S.; Mesquita, M. A.; Andrade, M. A.; Castejon, F. V.; Café, M. B.; Arnhold, E. and Leandro, N. S. M. 2015. Effect of period and storage temperature of hatching eggs from breeder quails on hatching results and quality characteristics of neonate quails. Arquivo Brasileiro de Medicina Veterinária e Zootecnia 67:1693-1702.

Araújo, I. C. S.; Leandro, N. S. M.; Mesquita, M. A.; Carvalho, H. H. C.; Café, M. B. and Gonzales, E. 2016. Effect of incubator type and broiler breeder age on hatchability and broiler chick quality. Brazilian Journal Poultry Science 18(spe.2):17-25.

Barbosa, V. M.; Cançado, S. V.; Baião, N. C.; Lana, A. M. Q.; Lara, L. J. C. and Souza, M. R. 2008. Efeitos da umidade relativa do ar na incubadora e da idade da matriz leve sobre o rendimento da incubação. Arquivo Brasileiro de Medicina Veterinária e Zootecnia 60:741-748.

Flauzina, L. P. 2007. Desempenho produtivo e biometria de vísceras de codornas japonesas alimentadas com dietas contendo diferentes níveis de proteína bruta. Dissertação (M.Sc.). Universidade de Brasília, Brasília, DF.

Garip, M. and Dere, S. 2011. The effect of storage period ant temperature on weight lossin quail eggs and the hatching weight of quail chicks. Journal of Animal Veterinary Advance 10:23632367.

Gomes, J. D. F.; Putrino, S. M. and Martelli, M. R. 2007. Morfologia de órgãos digestivos de suínos de linhagens modernas durante as fases de crescimento, terminação e pós-terminação. Acta Scientiae Animal Science 29:261-266.

Leandro, N. M.; Ali, R., Koci, M.; Moraes, V.; Eusebio-Balcazar, P. E.; Jornigan, J.; Malheiros, R. D.; Wineland, M. J.; Brake, J. and Oviedo-Rondon, E. O. 2011. Maternal antibody transfer to broiler progeny varies among strains and is affected by grain source and cage density. Poultry Science 90:2730-2739.

Lemos, M. J.; Calixto, L. F. L.; Reis, T. L. and Rego, R. S. 2014 Qualidade de ovos de poedeiras semipesadas de diferentes idades armazenados em diferentes temperaturas. Ciências Agrárias e Ambientais 12:133-140.

Luna, L. G. 1968. Haematoxylin-eosin staining. p.32-37. In: Manual of histologic staining methods of the Armed Forces Institute of Pathology. 3rd ed. American Registry of Pathology. McGraw- Hill, New York, NY.

Mahmud, A.; Khan, M. Z. U.; Saima, P. and Javed, M. A. 2011. Effect of different storage periods and temperatures on the hatchability of broiler breeder eggs. Pakistan Veterinary Journal 31:78-80.

Merlot, E.; Couret, D. and Otten, W. 2008. Prenatal stress, fetal imprinting and immunity. Brain Behavior Immunity 22:42-51.

Molenaar, R.; Reijrink, I. A. M. and Meijerho, R. and van den Brand, H. 2008. Relationship between hatchling length and weight on later productive performance in broilers. World Poultry Science Journal 64:599-604.

Nangsuay, A.; Meijerhof, R.; Ruangpanit, Y.; Kemp, B. and van den Brand, H. 2013. Energy utilization and heat production of embryos from eggs originating from young and old broiler breeder flocks. Poultry Science 92:474-482.

Nazareno, A. C.; Silva, I. J. O.; Vieira, A. M. C. and Vieira, F. M. C. 2014. Microclima, idade das matrizes e tempo de estocagem influenciando nas respostas produtivas de ovos férteis. Revista Brasileira de Engenharia Agrícola e Ambiental 18:1172-1178.

Oznurlu, Y.; Celik, I.; Telatar, T. and Sur, E. 2010. Histochemical and histological evaluations of the effects of high incubation temperature on embryonic development of thymus and bursa of Fabricius in broiler chickens. British Poultry Science 51:43-51.

Pedroso, A. A.; Café, M. B.; Leandro, N. S. M.; Stringhini, J. H. and Chaves, L. S. 2006. Desenvolvimento embrionário e eclodibilidade de ovos de codornas armazenados por diferentes períodos e incubados em umidades e temperaturas distintas. Revista Brasileira de Zootecnia 35:2344-2349.

Pereira, V. L. A. 2004. Qualidade de frangos de corte ao abate pela relação entre peso, doença de gumboro e algumas enfermidades associadas. Tese (D.Sc.). Universidade Federal Fluminense, Rio de Janeiro.

R Development Core Team. 2011. R: A language and environment for statistical computing. R Foundation for Statistical Computing, Vienna, Austria.

Riccardi, R. R.; Malheiros, E. B. and Boleli, I. C. 2009. Efeito do jejum pós-eclosão sobre pintos de corte provenientes de ovos leves e pesados. Ciência Animal Brasileira 10:1013-1020.

Rocha, J. S. R.; Lara, L. J. C.; Baião, N. C.; Cançado, S. V.; Baião, L. E. C. and Silva, T. R. 2008. Efeito da classificação dos ovos sobre o rendimento de incubação e os pesos do pinto e do saco vitelino. Arquivo Brasileiro de Medicina Veterinária e Zootecnia 60:979-986.

Santos, T. C.; Murakami, A. E.; Oliveira, C. A. L.; Moraes, G. V.; Stefanello, C.; Carneiro, T. V.; Feitosa, C. C. G. and Kaneko, I. N. 2015. Influence of european quail breeders age on egg quality, incubation, fertility and progeny performance. Brazilian Journal Poultry Science 17:49-56.

Tanure, C. B. G. S.; Café, M. B.; Leandro, N. S. M.; Baião, N. C.; Stringhini, J. H. and Gomes, N. A. 2009. Efeitos da idade da matriz leve e do período de armazenamento de ovos incubáveis no rendimento de incubação. Arquivo Brasileiro de Medicina Veterinária e Zootecnia 61:1391-1396. 
Teixeira, B. B.; Euclydes, R. B.; Silva, L. P.; Torres, R. A.; Silva, F. G.; Lenher, H. G. and Caetano, G. C. 2013. Herdabilidade de características de produção e postura em matrizes de codornas de corte. Ciência Rural 43:361-365.

Tona, K.; Bamelis, F.; De Ketelaere, B.; Bruggeman, V.; Moraes, V. M. B.; Byuse, J.; Onagbesan, O. and Decupyere, E. 2003. Effects of egg storage time on spread of hatch, chick quality, and chick juvenile growth. Poultry Science 82:736-741.
Vieira, V. R.; Nascimento, V. P.; Borsol, A. and Santos, L. R. 2007. Número mais provável (NMP) de Salmonella sp. em cecos de fangos de corte e correlação com a população linfocitária bursal. Acta Scientiae Veterinariae 35:49-53.

Zakaria, A. H.; Plumstead, P. W.; Romero-Sanchez, H.; Leksrisompong, N. and Brake, J. 2009. The effects of oviposition time on egg weight loss during storage and incubation, fertility, and hatchability of broiler hatching eggs. Poultry Science 88:2712-2717. 